Indo. J. Chem. Res., 2019, 7(1), 92 - 100

\title{
FITOAKUMULASI LOGAM Ni DAN Zn DALAM TUMBUHAN NIPAH (Nypa fruticans) DI SUNGAI TALLO MAKASSAR
}

\section{Phytoaccumulation of Nickel and Zinc in Nipah Plant (Nypa fruticans) at Tallo River, Makassar}

\author{
Nursiah La Nafie*, Syarifuddin Liong, Rizda Arifin \\ Department of Chemistry, Faculty Mathematic and Natural Science, Hasanuddin University, \\ Jl. Perintis Kemerdekaan 90245, Makassar-Indonesia \\ *Corresponding author, e-mail: nursiahlanafie@unhas.ac.id
}

Received: Feb. 2019 Published: Jul. 2019

\begin{abstract}
Research on phytoaccumulation of $\mathrm{Ni}$ and $\mathrm{Zn}$ in Nypa fruticans plants at Tallo River has been investigated. The aim of this research was to recognize the capability of Nypa fruticans in accumulating Ni and Zn. Water, sediment and plant tissue samples were taken from five stations in the Tallo River using the cutting tool and PVC pipe. Sediment was digested with concentrated $\mathrm{HNO}_{3}$ while plants tissues with $\mathrm{HNO}_{3} 6 \mathrm{M}$. then analyzed using ICP EOS Shimadzu 9000. The results showed the average concentration of Ni from the plant from station 1, 2, 3, 4 and 5 were 21,759.03 ppm; 19,056.03 ppm; 36,806.25 ppm; 10,736.66 ppm; and 13,849.25 ppm, respectively. Whereas the average concentration of $\mathrm{Zn}$ were $1,319.60 \mathrm{ppm} ; 1,362.93 \mathrm{ppm} ; 2,053.46 \mathrm{ppm}$; $1,591.60 \mathrm{ppm}$; and 1,474.09 ppm; respectively. The accumulation of $\mathrm{Ni}$ in Nypa fruticans was grouped as hyperaccumulation plant because the abilty of accumulation $\mathrm{Ni}$ was higher than $10,000 \mathrm{mg} / \mathrm{kg}$. The Bioconcentration Factor (BCF) and Translocation Factor (TF) values showed that Nypa fruticans were naturally potential to be used as phytoremediation plant towards $\mathrm{Ni}$, especially a phytoextraction and rhizofiltration.
\end{abstract}

Keywords: Ni, Zn, Nypa fruticans, phytoaccumulation, phytoremediation, Tallo River.

\section{PENDAHULUAN}

Laju pertumbuhan penduduk dan perkembangan kawasan industri di beberapa kota besar di Indonesia menimbulkan dampak positif dan dampak negatif. Dampak positif dari perkembangan kawasan industri adalah memperluas lapangan pekerjaan bagi masyarakat setempat, sedangkan dampak negatifnya adalah jumlah lahan pertanian semakin berkurang dan lingkungan menjadi tercemar oleh aktivitas industri (Erari, dkk., 2011). Limbah yang dihasilkan oleh industri seperti limbah padat, cair, dan gas. Limbah industri merupakan zat toksik yang berbahaya terutama yang mengandung logam berat. Masuknya polutan logam berat ke lingkungan (tanah, air, dan udara) menjadi perhatian serius karena berpotensi memiliki sifat toksik pada organisme baik tanaman, hewan maupun manusia (Darmono,1995). Beberapa logam berat yang dapat dijumpai di perairan pesisir dan laut adalah nikel (Ni) dan seng (Zn) (Khaira, 2014).
Beberapa upaya yang telah dilakukan untuk mengatasi pencemaran lingkungan oleh logam berat seperti metode kimia-fisika seperti proses pemisahan ion logam berat dengan resin penukar ion atau karbon aktif, elektrolisis dengan elektrokoagulator dan elektrokinetik. Namun cara ini relatif mahal dan kurang efektif. Alternatif lain yang dapat digunakan untuk mengurangi atau memulihkan polutan logam berat yaitu dengan tanaman tertentu yang dapat menyerap dan mengakumulasi logam berat dengan kosentrasi tinggi yang dikenal dengan fitoremediasi. Fitoremediasi merupakan salah satu metode remediasi dengan mengandalkan pada peranan tumbuhan untuk menyerap, mendegradasi, mentransformasi, dan memobilisasi bahan pencemar logam berat (Muliadi, dkk., 2013). David (2016), melakukan penelitian fitoakumulasi $\mathrm{Cd}$ dan $\mathrm{Zn}$ dalam mangrove Rhizophora mucronata di Sungai Tallo Makassar yang menunjukkan bahwa logam berat seperti Cd dan $\mathrm{Zn}$ dapat terakumulasi dari akar ke jaringan tumbuhan Rhizophora mucronata. Sedangkan Uddin (2015), telah melakukan 
penelitian akumulasi logam berat dan partisi bakau yang dapat dikonsumsi dan tidak dapat dikonsumsi di Delta Kalantan, Malaysia. Hasilnya menunjukkan bahwa logam berat seperti $\mathrm{Cu}$ mempunyai kadar yang tinggi pada akar dan daun Nypa fruticans.

Pada penelitian ini akan dilakukan studi fitoakumulasi Ni dan Zn pada tumbuhan Nypa fruticans di Sungai Tallo. Selain menentukan fitoakumulasi $\mathrm{Ni}$ dan $\mathrm{Zn}$ juga ditentukan kemampuan Nypa fruticans sebagai tumbuhan hiperakumulator terhadap logam tersebut, sehingga dapat memberikan informasi serta pemanfaatan Nypa fruticans dalam mengatasi pencemaran logam berat di perairan.

\section{METODOLOGI}

\section{Alat Penelitian}

Alat-alat yang digunakan pada penelitian ini adalah GPS, pipa PVC kantong sampel, ice box, botol polietilen, alat potong, oven SPN 150 SFD, tanur, neraca Ohaus AP 110, hot plate, ICP EOS Shimadzu 9000, cawan porselin, labu ukur, gelas piala, corong dan pipet volume.

\section{Bahan Penelitian}

Bahan-bahan yang digunakan pada penelitian ini adalah air sungai, sedimen, akar, pelepah, dan daun Nypa fruticans yang diperoleh dari sekitar Sungai Tallo, akuabides, HNO3 (Merck), $\mathrm{H}_{2} \mathrm{O}_{2}$ (Merck), standar multi-elemen 100 ppm (Merck), $\mathrm{Na}_{2} \mathrm{CO}_{3}$ (Merck), $\mathrm{K}_{2} \mathrm{CO}_{3}$ (Merck) dan kertas saring Whatman No. 42.

\section{Prosedur kerja \\ Penentuan Lokasi Sampling}

Posisi stasiun ditentukan secara acak, berdasarkan situasi dan kondisi yang berada di Sungai Tallo, yang dapat mewakili titik-titik pencemaran yang ada. Pengambilan sampel dilakukan pada lima titik (Gambar 1), yaitu :

1. Stasiun 1 berada dibelakang Mall Town Square Kota Makassar dan terletak pada koordinat S 5'8'37.904" dan E $119^{\circ} 28^{\prime} 45.737^{\prime \prime}$.

2. Stasiun 2 berada dekat dengan PLTU Kota Makassar dan terletak pada koordinat $\mathrm{S}$ $5^{\circ} 8^{\prime} 40.366^{\prime \prime}$ dan E $119^{\circ} 28^{\prime} 22.496$ '

3. Stasiun 3 berada di Pulau Lakkang dan terletak pada koordinat S $5^{\circ} 7^{\prime} 20.723$ " dan E $119^{\circ} 27^{\prime} 39.349^{\prime \prime}$
4. Stasiun 4 berada di Sungai Pampang dan terletak pada koordinat S $5^{\circ} 8^{\prime} 22.902$ " dan E $119^{\circ} 26^{\prime} 42.684^{\prime \prime}$

5. Stasiun 5 berada dekat dengan Kawasan Industri Makassar (KIMA) dan terletak pada koordinat S 5 6'53.650" dan E $119^{\circ} 26^{\prime} 59.092^{\prime \prime}$

\section{Pengambilan Sampel \\ Sampel Air Sungai}

Sampel air sungai diambil dari masingmasing stasiun dengan menggunakan water sampler sebanyak 1 L yang berada di pertengahan antara permukaan dan dasar sungai atau setengah dari kedalaman sungai. Sampel air sungai dipindahkan ke dalam botol polietilen, ditambahkan $\mathrm{HNO}_{3}$ pekat $5 \mathrm{~mL}$, lalu disimpan dalam ice box.

\section{Sampel Sedimen}

Sampel sedimen diambil dari masingmasing tempat dengan menggunakan pipa paralon lebih kurang 500 gram berat basah yang berada di permukaan. Pada setiap tempat, permukaan sedimen diambil dengan ketebalan sekitar $10 \mathrm{~cm}$, kemudian dimasukkan ke dalam plastik sampel.

\section{Sampel Tumbuhan Nypa fruticans}

Sampel pada bagian-bagian Nypa fruticans yaitu pada akar, pelepah dan daun. Akar yang diambil adalah akar pensil yang masuk ke dalam tanah dengan diameter 0,4-0,6 cm. Pelepah yang diambil adalah pelepah yang paling dekat dengan akar pohon Nypa fruticans sekitar $20-30 \mathrm{~cm}$ di atas permukaan air sungai dengan ukuran panjang $15-25 \mathrm{~cm}$. Daun yang diambil adalah daun tua berwarna hijau yang terletak paling dekat dengan akar pohon Nypa fruticans sekitar 20-30 cm di atas permukaan air sungai dengan ukuran panjang 9,7-13,9 $\mathrm{cm}$ dan lebar 2,8-4,7 $\mathrm{cm}$.

\section{Preparasi Sampel \\ Preparasi Sampel Air Sungai}

Sampel air sungai yang telah diambil di lapangan kemudian disimpan dalam lemari pendingin kemudian ditambahkan $1 \mathrm{~mL} \mathrm{HNO}_{3}$ pekat. 


\section{Preparasi Sampel Sedimen}

Sampel sedimen yang telah diambil di lapangan dikeringkan pada suhu $105{ }^{\circ} \mathrm{C}$ dengan menggunakan oven dan dihaluskan menggunakan lumpang. batu didih, lalu diuapkan hingga $10 \mathrm{~mL}$ di atas hot plate. Sampel disaring ke dalam labu ukur 50 $\mathrm{mL}$ lalu diencerkan hingga tanda batas dengan akuabides (larutan mencapai $\mathrm{pH} 2$ ), dihomogenkan. Kemudian dianalisis dengan ICP

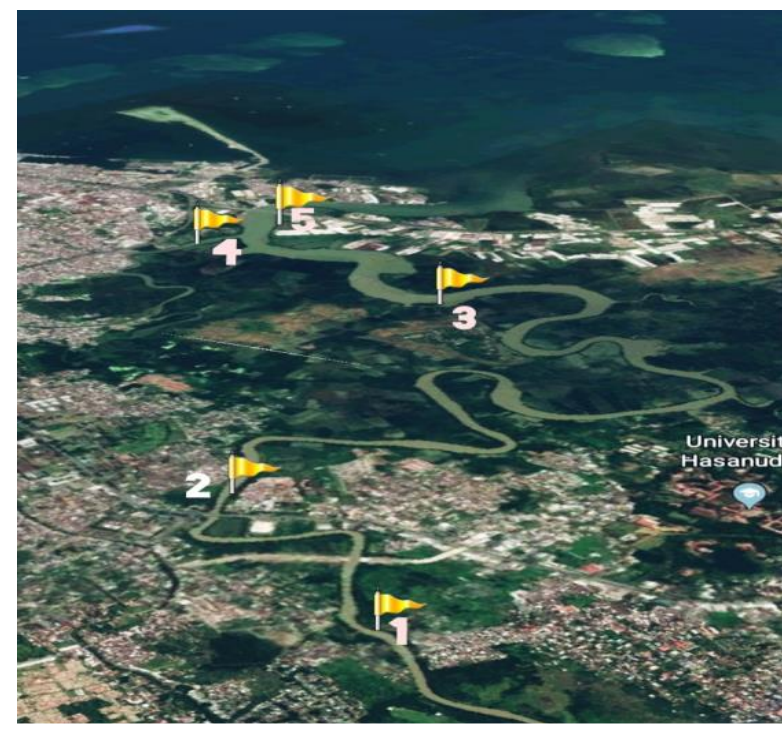

Gambar 1. Lokasi pengambilan sampel

\section{Preparasi Sampel Bagian Tumbuhan}

Sampel akar, pelepah dan daun masingmasing dicuci dengan aquades terlebih dahulu kemudian dikeringkan pada suhu $105^{\circ} \mathrm{C}$ selama 2 jam dengan menggunakan oven.
EOS Shimadzu 9000.

Destruksi dan Analisis Sampel Sedimen

Analisis $\mathrm{Ni}$ dan $\mathrm{Zn}$ dalam sedimen menggunakan teknik destruksi kering. Sampel sedimen yang telah kering didestruksi dengan cara menimbang 2,5 $\mathrm{g} \mathrm{Na}_{2} \mathrm{CO}_{3}$ ke dalam cawan

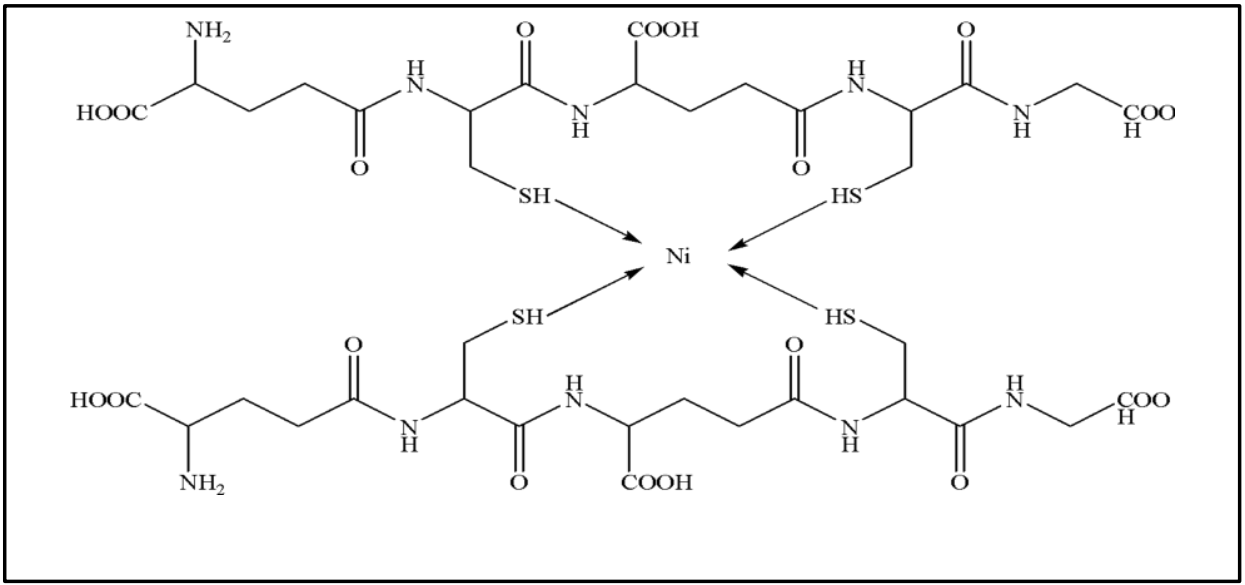

Gambar 2. Hasil Reaksi antara Fitokelatin dengan Ni

\section{Destruksi dan Analisis Sampel \\ Analisis Sampel Air Sungai}

Sampel air sungai dipipet sebanyak $50 \mathrm{~mL}$ ke dalam gelas kimia $100 \mathrm{~mL}$, kemudian dibubuhi $5 \mathrm{~mL} \mathrm{HNO}_{3}$ pekat dan ditambahkan porselin lalu ditambahkan $0,5 \mathrm{~g}$ sedimen dan ditambahkan lagi 2,5 g $\mathrm{NaHCO}_{3}$ hingga menutupi sampel sedimen, kemudian dimasukkan ke dalam tanur dan dipijarkan pada suhu $800{ }^{\circ} \mathrm{C}$ selama \pm 3 jam, didinginkan hingga 
suhu ruang dan ditambahkan $\mathrm{HNO}_{3} 4 \mathrm{M}$, lalu disaring ke dalam labu ukur $50 \mathrm{~mL}$ dan diencerkan hingga tanda batas dengan akuabides, dihomogenkan. Setelah itu larutan dipipet $1 \mathrm{~mL}$ ke dalam labu ukur $50 \mathrm{~mL}$, diencerkan hingga tanda batas dengan akuabides (larutan mencapai $\mathrm{pH}$ 2). Dihomogenkan kemudian dianalisis dengan ICP EOS Shimadzu 9000.

\section{Destruksi dan Analisis Sampel Bagian Tumbuhan}

Sampel akar, batang, pelepah, dan daun yang telah dikeringkan dalam oven kemudian didinginkan lalu masing-masing dihaluskan dengan lumpang. Setelah itu, ditimbang dengan teliti sebanyak 0,5 gram ke dalam gelas kimia $100 \mathrm{~mL}$ dan ditambahkan $5 \mathrm{~mL} \mathrm{HNO}_{3} 6 \mathrm{M}$ dan 2 $\mathrm{mL} \quad \mathrm{H}_{2} \mathrm{O}_{2}$ pekat untuk menghilangkan zat klorofilnya. Selanjutnya dipanaskan pada suhu $110{ }^{\circ} \mathrm{C}$ di atas hot plate hingga volume menjadi $\pm 1 \mathrm{~mL}$, kemudian disaring ke dalam labu ukur $50 \mathrm{~mL}$ dan diencerkan dengan akuabides, dihomogenkan. Setelah itu larutan dipipet $1 \mathrm{~mL}$ ke dalam labu ukur $50 \mathrm{~mL}$, diencerkan hingga tanda batas dengan akuabides (larutan mencapai $\mathrm{pH}$ 2). Dihomogenkan kemudian dianalisis dengan ICP EOS Shimadzu 9000.

\section{Penentuan Kadar Logam}

Pembuatan Deret Standar Larutan Ni dan Zn

Larutan standar multi-elemen $50 \mathrm{ppm}$ dibuat menjadi deret larutan baku standar Ni dan $\mathrm{Zn}$ menggunakan akuabides $\mathrm{pH} 2$. Larutan standar $\mathrm{Ni}$ dan $\mathrm{Zn}$ masing-masing dibuat 0,01 ppm; 0,05 ppm; 0,1 ppm; 1 ppm; 3 ppm; 5 ppm dan 10 ppm. Dianalisis dengan ICP EOS Shimadzu 9000 .

\section{Penentuan Konsentrasi Logam}

Konsentrasi logam yang didapatkan dari hasil analisa dengan menggunakan ICP dihitung dengan menggunakan persamaan (1) yang digunakan pada analisis logam berat sebagai berikut:

$$
\mathrm{C}=\frac{a x V x f p}{g}
$$

Keterangan:

$\mathrm{C}=$ konsentrasi sebenarnya $(\mathrm{mg} / \mathrm{kg})$ $\mathrm{a}=$ konsentrasi dari hasil analisis ICP $(\mathrm{mg} / \mathrm{kg})$

$\mathrm{V}=$ volume sampel $(\mathrm{L})$

$\mathrm{fp}=$ faktor pengenceran

$\mathrm{g}=$ massa sampel $(\mathrm{kg})$

\section{Mekanisme Fitoakumulasi Logam Berat}

Data berupa konsentrasi dari analisis sampel kemudian diolah dengan rumus penentuan nilai Translocation Factors (TF) dan Bioconcentration Factors (BCF) yang dituliskan pada persamaan (2) dan (3) sebagai berikut:

$$
\mathrm{TF}=\frac{[\mathrm{M}] \text { dalam dam }(\mathrm{mg} / \mathrm{kg})}{[\mathrm{M}] \text { dalam akar (mg/kg) }}
$$

$$
\mathrm{BCF}=\frac{[\mathrm{M}] \mathrm{rata}-\mathrm{rata} \text { dalam jaringan tumbuhan }(\mathrm{mg} / \mathrm{kg})}{[\mathrm{M}] \text { rata-rata dalam sedimen dan air (mg/kg) }}
$$

Nilai BCF dan TF selanjutnya digunakan untuk menentukan mekanisme penyerapan logam oleh tumbuhan. Menurut Gosh dan singh (2005) dalam Liong dkk (2010), jika nilai BCF > 1 dan $\mathrm{TF}<1$ mekanismenya adalah fitostabilisasi, $\mathrm{BCF}<1$ dan $\mathrm{TF}>1$ mekanismenya adalah fitoekstraksi.

\section{HASIL DAN PEMBAHASAN}

\section{Konsentrasi Logam Berat dalam Air Sungai Konsentrasi Ni dalam Air Sungai}

Logam berat dalam air sungai dapat berasal dari aktivitas manusia, limbah industri dan dapat pula berasal dari aktivitas gunung berapi (Nugraha, 2009). Limbah insdustri pada umumnya dibuang ke lingkungan tanpa pengolahan, sehingga dapat mengakibatkan menurunnya kualitas air sungai (Yudo, 2006). Hasil analisa $\mathrm{Ni}$ dalam air Sungai Tallo ditunjukkan pada Tabel 1.

Tabel 1. Konsentrasi Ni dalam air Sungai Tallo

\begin{tabular}{ll}
\hline Lokasi & Konsentrasi $(\mathrm{mg} / \mathrm{L})$ \\
\hline Stasiun 1 & 3,95 \\
Stasiun 2 & 3,36 \\
Stasiun 3 & 2,97 \\
Stasiun 4 & 8,79 \\
Stasiun 5 & 8,27 \\
\hline
\end{tabular}




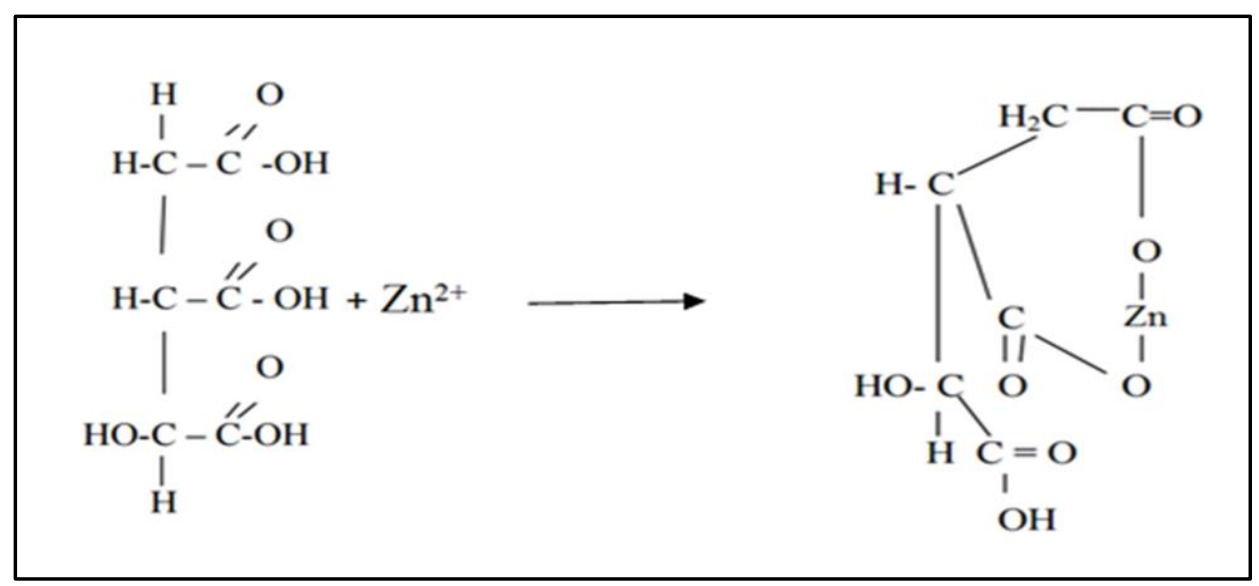

Gambar 3. Reaksi antara Asam Sitrat dengan Zn (Salisbury dan Ros (1995)

Hasil analisis menunjukkan konsentrasi $\mathrm{Ni}$ dalam air sungai pada semua stasiun yang bervariasi. Pada stasiun 4 mengandung konsentrasi Ni paling tinggi disebabkan karena berada pada sungai pampang dimana dekatnya dengan pemukiman masyarakat. Demikian juga pada stasiun 5 dimana berada pada pembuangan limbah Kawasan Industri Makassar sedangkan konsentrasi Ni dalam air Sungai Tallo yang paling rendah berada di stasiun 3 sebesar 2,97 $\mathrm{mg} / \mathrm{L}$. Besarnya konsentrasi Ni dalam air sungai telah melewati batas toleransi logam Ni dalam air sungai berdasarkan Surface Water Regulation of EU Directive Regulation oleh Environmental Protection Agency yaitu $3 \mathrm{mg} / \mathrm{L}$.

\section{Konsentrasi Zn dalam air Sungai Tallo}

Hasil analisis $\mathrm{Zn}$ dalam air Sungai Tallo ditunjukkan pada Tabel 2. Hasil analisis menunjukkan konsentrasi $\mathrm{Zn}$ dalam air sungai pada semua stasiun yang bervariasi. Pada stasiun 4 mengandung konsentrasi $\mathrm{Zn}$ paling tinggi dimana berada pada Sungai Pampang dimana terkontaminasi dengan aktivitas pembangunan dan dekatnya dengan pemukiman masyarakat. Begitupun stasiun 5 dimana berada sekitar pembuangan limbah Kawasan Industri Makassar.

Tabel 2. Konsentrasi Zn dalam air Sungai Tallo

\begin{tabular}{ll}
\hline Lokasi & Konsentrasi $(\mathrm{mg} / \mathrm{L})$ \\
\hline Stasiun 1 & 6,77 \\
Stasiun 2 & 4,56 \\
Stasiun 3 & 4,31 \\
Stasiun 4 & 11,12 \\
Stasiun 5 & 10,14 \\
\hline
\end{tabular}

Besarnya konsentrasi $\mathrm{Zn}$ dalam air sungai telah melewati batas toleransi logam $\mathrm{Zn}$ dalam air sungai berdasarkan Surface Water Regulation of EU Directive Regulation oleh Environmental Protection Agency yaitu $3 \mathrm{mg} / \mathrm{L}$.

\section{Konsentrasi Logam Berat dalam Sedimen Konsentrasi Ni dalam Sedimen}

Logam berat pada sedimen sangat bergantung pada aktivitas di sekitar aliran sungai. Logam berat yang masuk ke perairan akan mengalami pengendapan yang akan terakumulasi ke dalam sedimen. Konsentrasi logam berat dalam sedimen cenderung lebih tinggi dibanding konsentrasi logam berat dalam air (Sari, dkk., 2016). Hasil analisis Ni dalam sedimen di Sungai Tallo ditunjukkan pada Tabel 3.

\begin{tabular}{ll}
\multicolumn{2}{c}{ Tabel 3. Konsentrasi Ni dalam Sedimen } \\
\hline Lokasi & $\begin{array}{l}\text { Konsentrasi } \\
\text { (mg/kg berat kering) }\end{array}$ \\
\hline Stasiun 1 & $10.214,85$ \\
Stasiun 2 & $8.654,48$ \\
Stasiun 3 & $9.433,04$ \\
Stasiun 4 & $7.784,66$ \\
Stasiun 5 & $8.700,59$ \\
\hline
\end{tabular}

Hasil analisis menunjukkan bahwa konsentrasi Ni di semua stasiun hampir sama dengan konsentrasi terbesar terdapat pada stasiun 1 yaitu sebesar 10.214,85 dan konsentrasi paling kecil terdapat pada stasiun 4 yaitu sebesar 7.784,66. Konsentrasi Ni yang besar pada stasiun 1 disebabkan karena stasiun 1 berada dibelakang Mall Town Square Makassar dan juga dekat dengan pembuatan jalan. Besarnya konsentrasi logam Ni dalam sedimen telah melewati batas 
toleransi logam Ni dalam sedimen berdasarkan Ontario Ministry of the Environment yaitu 75 $\mathrm{mg} / \mathrm{kg}$.

\section{Konsentrasi Zn dalam Sedimen}

Hasil analisis $\mathrm{Zn}$ dalam sedimen di Sungai Tallo ditunjukkan pada Tabel 4. Hasil analisis menunjukkan bahwa konsentrasi $\mathrm{Zn}$ di semua stasiun cukup beragam dengan konsentrasi terbesar terdapat pada stasiun 5. Konsentrasi Zn yang besar paling besar pada stasiun 5 yaitu sebesar $5.429,25 \mathrm{mg} / \mathrm{kg}$ sedangkan yang paling kecil berada pada stasiun 2 yaitu sebesar 16,11 $\mathrm{mg} / \mathrm{kg}$. Konsentrasi Zn pada penelitian ini jauh lebih besar dibandingkan dengan hasil yang dilaporkan oleh David (2016) yang menyatakan bahwa konsentrasi Zn pada muara Sungai Tallo berkisar 145,06-338,55 mg/kg. Hasil penelitian ini menunjukkan peningkatan konsentrasi $\mathrm{Zn}$ dalam sedimen pada Sungai Tallo yang sangat besar dalam dua tahun terakhir. Hal ini disebabkan karena kurang terkontrolnya pembuangan limbah baik domestik maupun hasil industri ke perairan Sungai Tallo Makassar.

Tabel 4. Konsentrasi Zn dalam Sedimen

\begin{tabular}{ll}
\hline Lokasi & $\begin{array}{l}\text { Konsentrasi } \\
(\mathrm{mg} / \mathrm{kg} \text { berat kering })\end{array}$ \\
\hline Stasiun 1 & 464,43 \\
Stasiun 2 & 16,11 \\
Stasiun 3 & 739,33 \\
Stasiun 4 & $1.566,76$ \\
Stasiun 5 & $5.429,25$ \\
\hline
\end{tabular}

Konsentrasi logam berat dalam sedimen juga dapat dipengaruhi oleh konsentrasi logam berat dalam air. Konsentrasi logam berat dalam perairan dapat berasal dari limbah industri yang dibuang langsung ke perairan. Logam berat yang terdapat dalam perairan akan mengalami proses pengendapan dan akan terakumulasi dalam sedimen. Besarnya konsentrasi logam $\mathrm{Zn}$ dalam sedimen telah melewati batas toleransi logam $\mathrm{Zn}$ dalam sedimen berdasarkan Ontario Ministry of the Environment yaitu $820 \mathrm{mg} / \mathrm{kg}$.

\section{Konsentrasi Logam Berat dalam Bagian Tumbuhan Nipah}

Tumbuhan mangrove memiliki fungsi ekologis yaitu dapat menyerap, mengangkut, dan menimbun zat yang bersifat toksik yang berasal dari sekitar lingkungan tempat tumbuhnya, salah satunya logam berat. Mangrove dapat menyerap zat hara yang dapat sedimen maupun air dengan menggunakan akarnya (Setiawan, 2013).

\section{Konsentrasi Ni dalam Bagian Tumbuhan Nipah}

Hasil analisis logam Ni dalam bagian Tumbuhan Nipah dapat dilihat pada Tabel 5. Besarnya konsentrasi Ni dalam tumbuhan Nypa fruticans menunjukkan kemampuan tumbuhan tersebut dalam mengakumulasi logam berat dari lingkungannya, serta dapat mengurangi konsentrasi logam dalam air dan sedimen.

Penelitian ini dilakukan pada musim kemarau, sehingga tumbuhan akan melakukan proses transpirasi, yang dilakukan dengan tujuan untuk menyerap air dan zat hara yang berguna untuk mempertahankan atau mengatur suhu pada daun dan juga mengatur proses fotosintesis yang dilakukan tumbuhan (Simanjuntak, 2013). Menurut Rodrigo dkk. (2013), logam yang terserap ke dalam akar akan terikat dengan zat penghelat fitokelatin dengan logan $\mathrm{Ni}$ ketika proses transpirasi terjadi.

\section{Konsentrasi Zn dalam Bagian Tumbuhan Nipah}

Translokasi Zn ke jaringan-jaringan tumbuhan Nipah berbeda-beda setiap stasiun. Perbedaan variasi akumulasi logam ini disebabkan oleh beberapa faktor selain lingkungan, yaitu konsentrasi logam dalam sedimen, jenis logam, tingkat toleransi tumbuhan terhadap logam, usia tumbuhan, serta suhu yang ada pada lingkungan tumbuhan tersebut. Hasil analisis logam Ni dalam bagian tumbuhan Nipah dapat dilihat pada Tabel 6. Hasil akumulasi Zn dalam Tumbuhan Nipah, menunjukkan bahwa tumbuhan ini dapat menyerap $\mathrm{Zn}$ melalui akar sekitar 9,40-394,78 mg/kg dan dapat melakukan translokasi $\mathrm{Ni}$ ke pelepah sekitar 233,14$1.441,84 \mathrm{mg} / \mathrm{kg}$ dan sekitar 30,82- 991,60 mg/kg ke daun.

Logam yang terserap kedalam akar akan terikat dengan zat pengkelat seperti asam sitrat untuk Zn (Salisbury dan Ros, 1995). Menurut Salisbury dan Ros (1995), asam sitrat merupakan ligan terpenting dalam pengangkutan $\mathrm{Zn}$ melalui xylem yang kemudian ditranslokasikan ke jaringan lainnya seperti pada daun. 
Nursiah La Nafie dkk. / Indo. J. Chem. Res., 2019, 7(1), 92-100

Tabel 5. Konsentrasi Ni dalam Bagian Tumbuhan Nipah

\begin{tabular}{ccccc}
\hline Lokasi & \multicolumn{2}{c}{ Konsentrasi (mg/kg berat kering) } & Total \\
\cline { 2 - 4 } & Akar & Pelepah & Daun & \\
Stasiun 1 & $2.722,64$ & $18.231,07$ & 805,32 & $21.759,03$ \\
Stasiun 2 & $2.368,08$ & $16.240,28$ & 456,67 & $19.065,03$ \\
Stasiun 3 & $1.838,69$ & $15.184,39$ & $19.783,17$ & $36.806,25$ \\
Stasiun 4 & $1.656,17$ & $8.971,20$ & 109,29 & $10.736,66$ \\
Stasiun 5 & $1.511,97$ & $1.776,69$ & $10.200,59$ & $13.489,25$ \\
& & & & \\
Total & $10.097,55$ & $60.403,63$ & $31.355,04$ & $101.856,22$ \\
\hline
\end{tabular}

Tabel 6. Konsentrasi Zn dalam Bagian Tumbuhan Nipah

\begin{tabular}{ccccc}
\hline Lokasi & \multicolumn{3}{c}{ Konsentrasi } & Total \\
\cline { 2 - 4 } & Akar & Pelepah & Daun & \\
Stasiun 1 & 9,40 & $1.279,38$ & 30,82 & $1.319,60$ \\
Stasiun 2 & 14,93 & $1.290,61$ & 57,39 & $1.362,93$ \\
Stasiun 3 & 394,78 & $1.441,84$ & 216,84 & $2.053,46$ \\
Stasiun 4 & 292,26 & 494,20 & 805,14 & $1.591,6$ \\
Stasiun 5 & 249,35 & 233,14 & 991,60 & $1.474,09$ \\
Total & 960,72 & $4.739,17$ & $2.101,79$ & $7.801,68$ \\
\hline
\end{tabular}

Tabel 7. Nilai BCF dan TF logam Ni

\begin{tabular}{ccccccc}
\hline Lokasi & \multicolumn{4}{c}{ Konsentrasi (mg/kg berat kering) } & \multirow{2}{*}{ BCF } & TF \\
\cline { 2 - 5 } & Sedimen & Akar & Pelepah & Daun & & \\
Stasiun 1 & $10.214,85$ & $2.722,64$ & $18.231,07$ & 805,32 & 0,71 & 0,29 \\
Stasiun 2 & $8.654,48$ & $2.368,08$ & $16.240,28$ & 456,67 & 0,73 & 0,19 \\
Stasiun 3 & $9.433,04$ & $1.838,69$ & $15.184,39$ & $19.783,17$ & 1,30 & 10,75 \\
Stasiun 4 & $7.784,66$ & $1.656,17$ & $8.971,20$ & 109,29 & 0,46 & 0,06 \\
Stasiun 5 & $8.700,59$ & $1.511,97$ & $1.776,69$ & $10.200,59$ & 0,51 & 6,74 \\
\hline
\end{tabular}

Tabel 8. Nilai BCF dan TF logam Zn

\begin{tabular}{ccccccc}
\hline Lokasi & \multicolumn{4}{c}{ Konsentrasi (mg/kg berat kering) } & BCF & TF \\
\cline { 2 - 5 } & Sedimen & Akar & Pelepah & Daun & & \\
Stasiun 1 & 464,43 & 9,40 & $1.279,38$ & 30,82 & 0,94 & 3,27 \\
Stasiun 2 & 16,11 & 14,93 & $1.290,61$ & 57,39 & 28,20 & 3,84 \\
Stasiun 3 & 739,33 & 394,78 & $1.441,84$ & 216,32 & 0,92 & 0,54 \\
Stasiun 4 & $1.566,76$ & 292,26 & 494,20 & 805,14 & 0,33 & 2,75 \\
Stasiun 5 & $5.429,25$ & 249,35 & 233,14 & 991,60 & 0,09 & 3,97 \\
\hline
\end{tabular}

\section{Penentuan Tumbuhan Nipah (Nypa fruticans) Sebagai Hiperakumulator Ni dan Zn}

Tanaman hiperakumulator mampu mengakumulasi logam dengan konsentrasi 100 kali melebihi tanaman normal, dimana tanaman normal mengalami keracunan logam dan penurunan produksi. Hal ini terjadi karena adanya perbedaan serangkaian proses fisiologi dan biokimia serta ekspesi gen-gen yang mengendalikan penyerapan, akumulasi dan toleransi tanaman terhadap logam (Hidayati, 2005).

Semua jenis tumbuhan mampu untuk menyerap, mentranslokasikan, dan mengakumulasi logam, namun pada konsentrasi yang berbeda-beda. Tumbuhan Nipah 
menunjukkan kemampuannya untuk menyerap dan mengakumulasi logam Ni dan Zn melalui jaringan akar yang kemudian ditranslokasikan ke bagian tumbuhan lain seperti pelepah dan daun.

Data hasil analisis Ni pada tumbuhan Nypa fruticans menunjukkan bahwa tumbuhan Nypa fruticans di Sungai Tallo tergolong sebagai tumbuhan hiperakumulator terhadap Ni karena suatu tumbuhan disebut hiperakumulator terhadap Ni jika mampu mengakumulasi Ni lebih besar dari $10.000 \mathrm{mg} / \mathrm{kg}$ berat kering. Sama seperti logam $\mathrm{Ni}$, konsentrasi $\mathrm{Zn}$ yang terakumulasi dalam tumbuhan Nypa fruticans melebihi batas minimum yaitu $10 \mathrm{mg} / \mathrm{kg}$ berat kering, sehingga tumbuhan Nypa fruticans dikatakan sebagai hiperakumulator terhadap $\mathrm{Ni}$ dan Zn.

\section{Mekanisme Fitoakumulasi Ni dalam Tumbuhan Nipah (Nypa fruticans)}

Kemampuan tumbuhan

dalam

mengakumulasi dan mentranslokasikan logam dari tanah dapat diperkirakan dengan menggunakan perhitungan Bioconcentration Factors (BCF), dimana BCF dapat didefinisikan sebagai perbandingan antara rata-rata konsentrasi logam yang terdapat dalam jaringan tumbuhan dengan rata-rata konsentrasi yang terdapat pada tanah. Kemampuan suatu tumbuhan untuk mentranslokasi logam dari akar ke pucuk diukur dengan perhitungan Translocation Factors (TF), dimana TF dapat didefinisikan sebagai perbandingan antara konsentrasi logam yang terdapat pada pucuk dengan yang terdapat pada akar (Yoon dkk., 2006).

Pada dasarnya, BCF dan TF merupakan indikator yang dapat membedakan mekanisme akumulasi penyerapan logam oleh tumbuhan. Menurut Liong dkk.(2010) jika nilai BCF > 1 dan $\mathrm{TF}<1$ mekanisme adalah fitostabilisasi, $\mathrm{BCF}<1$ dan $\mathrm{TF}>1$ mekanismenya adalah fitoekstraksi, $\mathrm{BCF}<1$ dan $\mathrm{TF}<1$ mekanismenya adalah fitostabilisasi dan fitoekstrasi, dan jika $\mathrm{BCF}>1$ dan $\mathrm{TF}>1$ mekanismenya adalah rizofiltrasi. Tabel 7 menunjukkan nilai BCF dan TF untuk logam Ni.

Pada tabel 7 , diperoleh nilai BCF cukup bervariasi, nilai $\mathrm{BCF}$ tertinggi pada stasiun 3, yaitu sebesar 1,30. Sedangkan nilai BCF terendah berada pada stasiun 5 yaitu sebesar 0,51 . Sedangkan nilai TF yang tertinggi berada pada stasiun 3 yaitu sebesar 10,75. Sedangkan nilai TF yang paling rendah berada pada stasiun 4 yaitu sebesar 0,06 . Nilai BCF rata-rata untuk $\mathrm{Ni}$ adalah 0,74 dan nilai TF rata-rata untuk $\mathrm{Ni}$ adalah 3,60. Karena nilai BCF kurang dari 1 dan nilai TF lebih dari 1 sehingga tumbuhan Nipah (Nypa fruticans) memiliki potensi sebagai tumbuhan jenis fitoekstraksi untuk logam Ni.

\section{Mekanisme Fitoakumulasi Zn dalam Tumbuhan Nipah (Nypa fruticans)}

Mekanisme fitoakumulasi logam $\mathrm{Zn}$ dalam tumbuhan Nipah (Nypa fruticans) dapat dilihat pada Tabel 8. Pada tabel 8 , diperoleh nilai $\mathrm{BCF}$ cukup bervariasi, nilai BCF tertinggi pada stasiun 2, yaitu sebesar 28,20. Sedangkan nilai BCF terendah berada pada stasiun 5 yaitu sebesar 0,09 . Sedangkan nilai TF yang tertinggi berada pada stasiun 5 yaitu sebesar 3,97. Sedangkan nilai TF yang paling rendah berada pada stasiun 3 yaitu sebesar 0,54. Nilai BCF rata-rata untuk $\mathrm{Zn}$ adalah 6,09 dan nilai TF ratarata untuk $\mathrm{Zn}$ adalah 2,87. Oleh karena nilai BCF lebih dari 1 dan nilai TF lebih dari 1 sehingga tumbuhan Nipah (Nypa fruticans) memiliki potensi sebagai tumbuhan jenis rhizofiltrasi untuk logam Zn.

\section{KESIMPULAN}

Berdasarkan hasil penelitian maka dapat disimpulkan bahwa translokasi $\mathrm{Ni}$ dan $\mathrm{Zn}$ terakumulasi paling besar pada bagian pelepah, mekanisme penyerapan untuk $\mathrm{Ni}$ adalah fitoekstraksi dan $\mathrm{Zn}$ adalah rhizofiltrasi. Total akumulasi Ni dan Zn dalam tumbuhan Nypa fruticans menunjukkan secara alami tumbuhan ini hiperakumulator terhadap $\mathrm{Ni}$.

\section{DAFTAR PUSTAKA}

Darmono, 1995, Logam Dalam Sistem Biologi Makhluk Hidup, UI-Press, Jakarta.

David, M., 2016, Fitoakumulasi Logam Cd dan Zn dalam Tumbuhan Bakau Rhizopora mucronata di Sungai Tallo Makassar, Skripsi tidak diterbitkan, Universitas Hasanuddin, Makassar.

Erari, S.S., Mangimbulude, J., Lewerissa, K., 2011, Pelestarian Hutan Mangrove Solusi Pencegahan Pencemaran Logam Berat di Perairan Indonesia, Biologi Sains Lingkungan, dan Pembelajarannya Menuju Pembangunan Karakter, 8 (1), 182-186. 
Hidayati, N., 2005, Fitoremediasi dan Potensi Tumbuhan Hiperakumulator, Hayati, 12 (1), $35-40$.

Khaira, K., 2014, Analisis Kadar Tembaga (Cu) dan Seng (Zn) dalam Air Minum Isi Ulang Kemasan Galon di Kecamatan Lima Kaum Kabupaten Tanah Datar, J. Saintek, 2(6), 116-123.

Liong, S., Noor, A., Taba, P., Abdullah A., 2010, Studi Fitoakumulasi $\mathrm{Pb}$ dalam Kangkung Darat (Ipomoea reptans Poir), Skripsi, Jurusan Kimia Fakultas MIPA Universitas Hasanuddin, Makassar.

Muliadi, Liestianty, D., Yanny, Sumarna, S., 2013, Fitoremediasi : Akumulasi dan Distribusi Logam Berat Nikel, Cadmium dan Chromium dalam Tanaman Ipomea reptana, Prosiding Seminar Nasional Kimia dan Pendidikan Kimia, 1-5.

Nugraha, W.A., 2009, Kandungan Logam Berat pada Air dan Sedimen di Perairan Socah dan Kwanyar Kabupaten Bangkalan, $J$. Kelautan, 2(2),158-163.

Ontorio Ministry of the Environment, 2008, Guidelines for Identfying, Assessing and Managing Contaminated Sediment in Ontario: An Integrated Approach.

Rodrigo, M.A.M., Cernei, N., Kominkova, M., Zitka, O., Beklova, M., Zehnalek, J., Kizek, R., Adam, V., 2013, Ion Exchange Chromatography and Mass Spectrometric Methods for Analysis of CadmiumPhytochelatin (II) Complexes, Int. J. Environ. Res. Public Health, 10 (4), 13041311.

Salisbury F.B., Ross, C.W., 1992, Fisiologi Tumbuhan Jilid 1, diterjemahkan oleh:
Lukman, D.R., dan Sumaryono, 1995, ITB, Bandung.

Sari, F.G.T., Hidayat, G., Septiani, P.D., 2016, Kajian Kandungan Logam Berat Mangan dan Nikel pada Sedimen di Pesisir Teluk Lampung, Analytical and Environmental Chemistry, 1(1), 17-25.

Setiawan, H., 2013, Akumulasi Dan Distribusi Logam Berat Pada Vegetasi Mangrove Di Perairan Pesisir Sulawesi Selatan, J. Ilmu Kehutanan,

7 (1), 12-24.

Simanjuntak, E.T., 2013, Alat Pengukur Laju Transpirasi Pada Daun Berbasis Mikrokontroler, Skripsi, Fakultas Teknik Elektronika dan Komputer, Universitas Kristen Satya Wacana, Salatiga.

Uddin, M.M, 2015, Is Phytoremediation an Ecosystem Service? Heavy Metal Accumulation and Partitioning of Consumable and Non-Consumable Mangroves of The Kalantan Delta, Peninsular Malaysia, Disertasi Tidak Diterbitkan, Biology, Vrije Universiteit Brussel, Brussel, Belgium.

Yoon, J., Cao, X., Zhou, Q., dan Ma, L. Q., 2006, Accumulation of $\mathrm{Pb}, \mathrm{Cu}$, and $\mathrm{Zn}$ in Native Plants Growing On a Contaminated Florida Site, Science of the Total Environment, 368, 456-464.

Yudo, S., 2006, Kondisi Pencemaran Logam Berat Di Perairan Sungai DKI Jakarta, JAI, 2(1), 1-15. 
Nursiah La Nafie dkk. / Indo. J. Chem. Res., 2019, 7(1), 92-100 